\title{
Reputation risk in banking: application for Ukraine
}

Anna Buriak

$\mathrm{PhD}$, Department of Finance, Banking and Insurance, Sumy State University, Ukraine.

Aleksandr Artemenko

Master in Economics, Sumy regional administration Oschadbank, Ukraine.

\begin{abstract}
The paper examines the reputation risks in banking. Soundly, that the reputation risk of a bank is a socioeconomic category, which can serve as a quantitative assessment (indicator) of the level of public trust in the bank, and is characterized by the present or potential risk for revenues and capital, the reasons of which are both internal and external, and the consequences there is a deterioration in the financial condition, loss of the client base and other circumstances that do not meet the expectations of the bank. The use of integral indicator of reputational risk based on a combination of quantitative and ballistic estimation using taxonomic analysis tools is proposed.
\end{abstract}

Key words: reputation, risks, reputation index, banking.

JEL Classification: G21, G210, G32.

(C) The Authors, 2018. This article is published with open access at Sumy State University.

\section{Introduction}

One of the main causes of global and domestic financial crisis was the loss of trust from customers and spreading negative reputation of financial institutions. Nowadays, the positive business reputation of a financial intermediary can be considered an indicator of public confidence in the financial sector at the institutional level. The risk of loss of business reputation, in other words reputational risk, becomes more and more important in comparison with other financial and non-financial risks of banking activity. Relevance of the research topic reputational risks in the banking sector caused by the urgent need of all financial sector stakeholders to establish trust relationships to ensure the circulation of funds in the economy recovery and the positive reputation of financial intermediaries. The complexity of the study of reputational risk is explained by its unpredictability in the manifestation and size of losses incurred by the bank, the specific form of reputation as an intangible asset, as well as the limited capacity for quantitative risk assessment, in circumstances where the efficiency of the bank is increasingly determined by public opinion and customer confidence.

\section{Reputation risk in banking: approaches and evaluation}

According to Jean Paul Luíto, "there is no such thing as a reputation risk, but all risks can have an impact on the reputation of the organization." Banking business is built and based on customer confidence. Reputation is a general assessment of the company's activities of the bank, as well as the actions of its real owners, and its impact is unpredictable. Connie M. Frisen suggested defining a business reputation as an intangible asset that forms the competitive position of the organization on the market, but at the same time it is one of the most ambiguous and difficult to measure.

For the interpretation of the reputation risk of the bank by Ukrainian legislation in the banking sector, it is necessary to pay attention to "Methodological recommendations on the organization and functioning of risk management systems in banks of Ukraine", namely paragraph 13.1. Accordingly, reputational risk is defined as the present or potential risk for bank revenues and capital, formed on the adverse factors of the image of the institution, clients, participants (shareholders) or the regulator, represented by the National Bank of Ukraine. In our opinion, this approach is rather limited, given that the image, as was reasonably stated above, is only one of the components of the reputation of the bank, and therefore the factors of influence are limited.

According to the US Federal Reserve, reputational risk can be identified as a cause. That is, it is a complex category that involves unsuccessful use of the brand, the provision of poor quality service or deviation from the rules of the law (the reason), resulting in the bank receiving damages (the effects of the risk) caused by a decrease in the confidence of customers and other stakeholders in long-term period. In turn, the Bank of England considers the risk as an object of use, and reputational risk is defined as a rating factor, which is very important for high-quality financial institutions to reliably distinguish itself from low-quality banks that are likely to have poor reputation and low market cost. 
A structural approach to the treatment of reputational risk is noteworthy, according to Deutsche Bundesbank. Definition of the concept can be divided into three components: formation, detection and consequence. Thus, reputational risk is defined as a formed category when the expectations of the parties significantly exceed the operational capabilities of the company; appears when interested parties believe that the bank is already fundamentally not in line with their expectations, and the consequence of these circumstances is economic losses (Bundesbank: official web-portal).

The next step is to analyze the position of the Basel Committee on Banking Supervision to the investigated aspect. In accordance with Basel II, or rather, paragraph 732, when assessing the capital adequacy of a bank, all risks having an economic entity's place of business must be taken into account, while item 742 emphasizes that reputation must necessarily be included in these risks (Basel II, 2005).

Summarizing the above information, we propose to continue to work under the reputational risk of the bank to understand the socio-economic category, which is characterized by the present or potential risk for revenues and capital, the reasons of which are both internal (inappropriate corporate governance and the reputation of top management of the bank, as well as its owners , unsuccessful use of the brand, the provision of poor quality services or deviation from the rules of law, operational errors of employees, cases of fraud, etc.) and external (negative representation of financial status, quality of services from clients, conflict of interests, client bank, negative feedback on the bank's activities in the media, unethical behavior of competitors, etc.), and the consequences are deteriorating financial status, loss of client base, termination of transactions and other circumstances that do not meet the expectations of the bank.

Traditionally, the distribution of evaluation methods is carried out on a quantitative and qualitative analysis. As for qualitative analysis, the method deserves the greatest attention under the name "reputation indexes", although it is worth noting that hep analysis is also quite common. So-called reputational risks are a kind of analogy to the method of expert judgment. The common feature of these models is that they are focused on polling and rating: they offer experts (respondents) to express their opinion about the bank with reference to a certain set of reputational measurements, followed by the transfer of results to the synthetic score.

The most used reputation indexes are:

$>$ Fortune` Overall reputation quotient (AMAC and GMAC);

> The reputation Institute`s Reputation Quotient (from 2006 RepTrak System);

Merco`s rating (Business Monitor of Corporate Reputation) [8].

The main difference between these estimates is the various classification determinants of reputation.

In terms of quantitative assessment, it is customary to distinguish three main approaches in foreign practice: organizational, accounting and marketing approaches (Giorgino). The best-known of them is goodwill, which belongs to the accounting approach. In this case, the goodwill is called the result on the basis of the previous study of the indicators of reputation, which enables to estimate the future excess of the bank's profitability compared to the average results in the market. It is calculated as the difference between the company's purchase value and the market value of "net" assets (Kolesnik, 2016).

Widespread methods of stock volatility, abnormal returns and the policy-capturing survey method (Giorgino). The method of abnormal profit is based on risk assessment by studying the reaction of changes in the prices of shares of the bank prior to the announcement of a significant risk event, which will be accompanied by reputational losses. The percentage of losses is calculated as losses divided by the market capitalization of the firm, and the market model is used to determine abnormal returns for each organization. An abnormal return on a bank is defined as the difference between actual returns and expected returns based on one factor of the market model, and any fall in the market value of an organization that exceeds the declared amount is treated as a loss of reputation.

The stock volatility method is based on observing stock price fluctuations, but this model does not take into account direct losses that result from risk events. It focuses exclusively on the volatility of stock prices.

The last of these methods does not provide an actual quantification of reputational risk (since it applies a survey to generate a risk understanding), but forms an interesting perspective on the analysis. The basis of the approach is direct involvement of the bank's stakeholders and their reaction to the proposed scenarios, followed by an assessment of their decisions by industry experts. In the next step, the results are analyzed 
using a multimodal logistic model, and coefficients are formed that correspond to the influence of reputation signals on each of the decisions made. On the way out, we have a link between a reputational scenario and the behavior of stakeholders. Although this method is not an actual assessment of reputational risk, it is a stimulating approach to understanding the causes and effects of the risk under investigation (Giorgino). Summarizing, we can conclude that there is a wide range of methods for assessing the level of reputation risk of the bank, with each of them having its disadvantages and advantages in applying in a particular situation. Thus, in the quantitative group, the most acceptable use is considered a market valuation, or goodwill, which is the most widespread foreign country and is based on the difference between the company's purchase value and the market value of "net" assets. Although taking into account the state of the stock market of Ukraine, which does not allow to engage in technical analysis, its relevance is minimized. As for the characteristics of qualitative approaches, the method of expert assessments deserves the greatest attention. In practice, it is the most common, and its models are based on the analysis of risk assessments provided by experts, but the main disadvantage of the method is its subjectivity, as well as work in complete uncertainty and the use of limited amounts of information. In foreign practice, the analogy of this approach is called "reputation index," with the common feature of these models being that they are focused on polling and rating, and the main difference is different classification criteria of reputation (Jackson (2009); Sturm P. (2013); Wyman).

\section{Ukrainian banking system: determinants of reputation risk}

Financial determinants. Reputational risk is non-financial because of its economic nature, at the same time it does not exclude the essential importance of financial factors, in particular financial performance of banks, in maintaining a positive business reputation. Figure 1, which summarizes the financial results of the Ukrainian banking system, is a direct reflection of socio-political and economic instability, which became the starting point for increasing reputational risks. The banking system of Ukraine is only gradually moving away from the shocking state of 2014-2015 and is characterized by low activity of credit institutions, the main obstacle for which is the further uncertainty about vectors of economic development and reduction of purchasing power of clients, which manifests itself in reducing the number of reliable borrowers. So, the loss in 2016 was a record for the period of existence of an independent Ukraine, with the previous maximum result recorded in 2015. The decrease in revenues in 2016 compared to previous periods was primarily caused by losses from trading in foreign currency and bank metals, as well as by the gradual reduction of interest income (as of January 1, 2017 their volume decreased by almost 60\%). It should be noted that since the beginning of the crisis period, the fluctuations of the national currency rate, along with the gradual withdrawal of some banks from the market (under the policy of "rehabilitation") and the general reduction of credit portfolios of commercial banks, had a significant impact on the performance of the Ukrainian banking system.

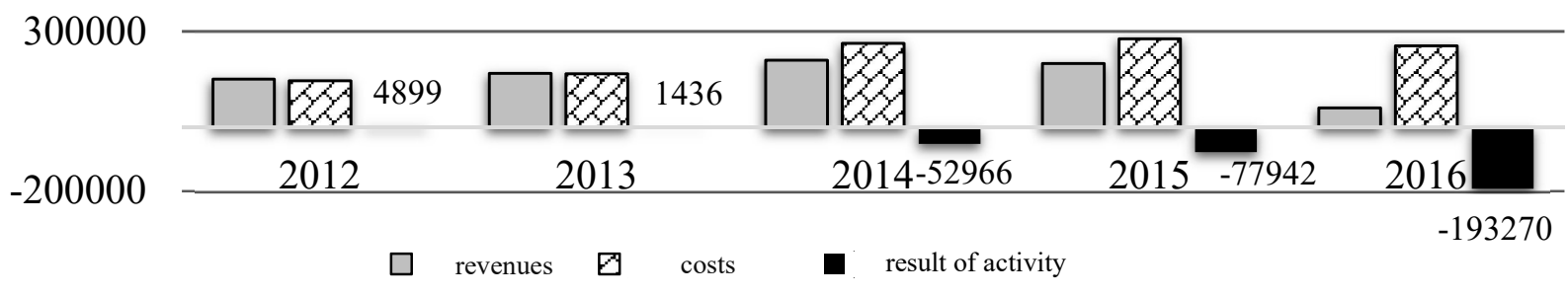

Figure 1. Financial result of the banking system of Ukraine as of 01.01.2013 - 01.01.2017, mln. UAH.

According to the results of 2016, 35 commercial banks out of a total of 95 institutions suffered losses totaling about 206.8 billion UAH, while the lion's share (79.7\%) falls on PJSC CB "PrivatBank". The remaining 60 banks completed the period with a positive result of activity, which totaled about 13.6 billion UAH. (Table 1). Along with PJSC CB "PrivatBank" to the top three most unprofitable also include PJSC "Ukrsotsbank" and PJSC "VTB Bank", but one should bear in mind that the scale of losses and the situation caused by them can not be compared. According to Table 1, only foreign banks are the most profitable, among them Raiffeisen Bank Aval (leader of 2016), Citibank (undisputed leader of 2015) and OTP Bank, which accounted for about $57.5 \%$ of the total income of the banking system of Ukraine, are especially distinguished. If we take into account the volume of assets, the most unprofitable group of private capital banks, which accounts for $97.5 \%$ in the total amount of assets of the system, while they gave only $9.3 \%$ of profit for 2016 . It has been established that from the point of view of the banking system of Ukraine, the group of financial factors deserves the most attention, namely aspects of financial stability, which in turn will affect the business activity of banks and the trust of clients. If we take into account PJSC CB "PrivatBank", the group of derivative risks deserves the most 
attention, namely, the corporate one, which resulted in the process of nationalization of the bank, against the backdrop of an increase in lending to related parties and a corresponding increase in problem debt as a key factor in lowering customer confidence .

Table 1. Profit and unprofitable banks broken down by groups as of 01.01.2017

\begin{tabular}{|l|c|c|c|c|c|c|c|c|}
\hline \multirow{2}{*}{ Group } & \multicolumn{2}{|c|}{ Number of banks } & \multicolumn{3}{c|}{ Unprofitable } & \multicolumn{3}{c|}{ Profitable } \\
\cline { 2 - 9 } & од. & $\%$ & од. & $\%$ & $\begin{array}{c}\text { Damage mln. } \\
\text { UAH. }\end{array}$ & unit & $\begin{array}{c}\text { Profit mln. } \\
\text { UAH. }\end{array}$ & 3659 \\
\hline Banks with a state interest & 6 & 100 & 3 & 50.0 & 165885 & 3 & 50,0 & 3659 \\
\hline Banks of foreign bank groups & 25 & 100 & 9 & 36.0 & 38367 & 16 & 64.0 & 8688 \\
\hline Banks with private capital & 59 & 100 & 18 & 30.5 & 1254 & 41 & 69.5 & 1266 \\
\hline Insolvent banks & 5 & 100 & 5 & 100 & 1376 & - & - & - \\
\hline Total & 95 & 100 & 35 & 36.8 & 206882 & 60 & 63.2 & 13613 \\
\hline
\end{tabular}

Trust as nonfinancial determinant. The main factor of reputation is the trust of clients to the institution (leading UniCreditBank analyst Andriy Prykhodko claims that the low level of trust in the banking system is the first in the list of threats and risks in 2017), as well as the general economic situation in the state that indirectly affects the financial stability and performance of the banking system of Ukraine. According to the results of the Razumkov Center survey (as of the 2nd quarter of 2013), only $2 \%$ are absolutely sure of the reliability of the banking system, $15 \%$ have expressed the opinion that they trust the creditor rather than the reverse, $43 \%$ - do not trust, the rest of the people are not clearly identified. If to analyze the research of the Democratic Initiative Foundation this year, but four months later, then $37 \%$ of people do not trust banks at all and only $21.9 \%$ trust it (Somyk). The ratings are interesting by the American Gallup Institute, which makes it possible to compare the results of 2012 and 2016 (135 countries participate in the study, with a sample of 1,000 people from each state). Accordingly, in 2012, 31\% of the respondents surveyed were positive about the attitude towards the banking system of Ukraine, whereas about $53 \%$ were skeptical. Interestingly, it was during this period that the deterioration in the position of the UK ( $27 \%$ of the population trust the banks), Hungary (26\%), Italy (20\%) and Spain (18\%), which was the result of a protracted debt crisis. In 2016, the situation is projected to deteriorate and only $18 \%$ have expressed confidence in the banking sector, with a negative opinion of almost $66 \%$.

The rapid rate of depreciation of the national currency of Ukraine contributed to a rise in distrust in the banking system, which was accompanied by the outflow of deposits from banks in the hryvnia. In general, the change in exchange rates has had a sharp negative impact not only on investing in banks, but also on servicing loans received, resulting in an increase in the number of overdue debts, which in turn affects the financial component in the group of internal factors of reputational risk. Thus, the analysis of external factors of influence on the level of reputation risk of the bank makes it possible to establish that the main factor is the trust of clients, which is formed on the basis of the indirect influence of a group of economic and legal factors. In turn, economic factors are determined by the geoeconomic situation and the pace of a gradual exit from the crisis, although GDP growth is occurring, but in dollar terms it stood at the level of 2005. At the same time, the legal and legal risks associated with the unjustified adoption of certain decisions by the National Bank of Ukraine and the lack of transparency of activity in terms of certain aspects, which, combined with low level of financial literacy of citizens, have a significant impact on the formation of customer confidence in banks.

\section{Methods and results}

In order to assess the reputation risk of the bank, an integrated indicator of its level (IRRi) was proposed with the use of taxonomic analysis tools, the calculation of which consists of the following stages (Pribor CB "PrivatBank"):

$>$ justification of the criteria for assessing the reputation risk of PJSC CB "PrivatBank" and selection for each of them of partial indicators of reputational risk, based on a combination of the results of the quantitative and the ball assessment;

$>$ the establishment of binary characteristics for ballroom assessment and the formation of a research base by standardizing the data of partial indicators, after checking their values for multicollinearity;

determination of risk stimulants and disintegrators; formation of vector-standard;

Determination of IRR indicator of PJSC CB "PrivatBank" and qualitative interpretation of the results on the basis of Chaddock's scale of interconnection. 
The first two stages of calculating the integral index of reputation risk of a bank require the formation of groups of factors of influence with the subsequent selection of indicators for each of them. Thus, it is proposed to form a block of basic financial ratios of PJSC CB "PrivatBank", which includes financial stability, efficiency of activities, indicators of liquidity and business activity. To the group of criteria for the assessment of reputation risk PJSC CB "PrivatBank" it is proposed to include three blocks - the image and organizationalfunctional unit, a group of factors of the internal environment of the bank (Fig. 2).

Factors of the image component $\left(I_{1}-I_{7}\right)$

reputation of founders and major shareholders $\left(I_{1}\right)$; social and business activity of the bank $\left(I_{2}\right)$; perception of the market of banking products offered by the bank $\left(I_{3}\right)$;

the association of shareholders with the political environment, lobbying the interests of the bank on the basis of political relations $\left(I_{4}\right)$;

level of disclosure about the bank $\left(I_{5}\right)$;

inefficiency of counteraction to legalization of incomes; obtained by a criminal way, as well as other illegal activities $\left(I_{6}\right)$

deterioration of image at the state level $\left(I_{7}\right)$.
Organizational and functional component $\left(\mathrm{O}_{1}-\mathrm{O}_{6}\right)$

- $\quad$ - quality of customer service, cases of negative appeals and complaints $\left(\mathrm{O}_{1}\right)$;

- $\quad$ - Litigation relating to the Bank's activities $\left(\mathrm{O}_{2}\right)$;

- $\quad$ - Monitoring of mass media messages $\left(\mathrm{O}_{3}\right)$;

- $\quad$ - The level of popularity of its own payment system $\left(\mathrm{O}_{4}\right)$;

- $\quad$ - associated with the transformation of other risks (credit, operating) $\left(\mathrm{O}_{5}\right)$;

- $\quad$ - results of bank audits by state regulation bodies $\left(\mathrm{O}_{6}\right)$;

Factors of the internal environment $\left(B_{1}, B_{2}\right)$

- processes of internal corporate communications $\left(B_{l}\right)$

- adequacy of the existing system of internal control and audit $\left(B_{2}\right)$.

Figure 2. Nonfinancial factors affecting reputational risks of banks

Criteria scoring $\left(I_{1}-B_{2}\right)$ include common items that distinguish modern scholars and the group added the author, most significantly will reflect the specificity of the bank and the current market situation, for example:

- $\quad$ the association of the bank's shareholders with the political environment of the state;

- Lobbying the interests of the institution on the basis of "political ties";

- level of disclosure about the bank;

- inefficiency of counteraction, legalization of proceeds from crime, as well as other illegal activities;

- deterioration of the image of banks at the state level;

- The level of popularity of its own payment system;

- the criterion is related to the transformation of other risks (in this situation it is most relevant to assess the impact of credit risk on the reputation of PJSC CB "PrivatBank").

Appendix A shows the dynamic input partial indicators of reputational risk PJSC CB "PrivatBank" as of 01.01.2013 - 01.01.2017 years. The application is a set of input data necessary to create a standardized system of partial indicators of reputational risk PJSC CB "PrivatBank" (tab. A .1) and the formation of a vectorstandard (taking into account the exclusion of related risk indicators).

In general, the standardization process is carried out for the construction of indicators to a single meter, according to the formula (1):

$P_{i}=\frac{K_{i}}{\bar{L}_{i}}$,

Where $P_{i}$ - standardized value of a partial indicator of reputational risk;

$K_{i}$ - partial index for the period $i$;

$\overline{\mathrm{K}}_{\mathrm{i}}$ - the average value of the partial index for the period. 
The next step is to differentiate partial indicators, which is a mandatory procedure for the further formation of the vector-standard, and predicts their division into "stimulators" (with an increase in the index, the risk of reputation decreases) and "disintegrators" (the risk increases in parallel with the increase of the indicator):

$x_{0 i}=\left\{\max X_{i y}\right.$ stimulator $\mid \min X_{i y}$ disintegrator $\}$

The reason for the differentiation of partial indicators is the specific effect of each of them on the overall index of reputation risk of the bank. After that, we can formulate a standardized system of partial indicators as shown in Appendix E and provide a vector-standard (in the case where the partial indicator is determined by the stimulator for the standard it is considered its max value in the $i$-th period, if the trigger is the min result):

$P=(0,76 ; 1,08 ; 1,14 ; 1,52 ; 0,51 ; 1,18 ; 0,33 ; 1 ; 1 ; 0,29 ; 1 ; 0,45 ; 0,71 ; 0,45 ; 0,24 ; 1 ; 1 ; 0,29 ; 0,29 ; 0,71 ; 0,33)$

The following actions are related to the calculation of the taxonomic distance, which enables us to determine the location of each of the above depicted elements in the matrix of observations, the classification and streamlining of information in order to further analyze reputational risk. To do this we use the following formula:

$\mathrm{C}_{0 i}=\sqrt{\sum_{i=1}^{m}\left(P_{i j}-P_{0 i}\right)^{2}}$,

where $P_{i j}$ - the value of the standardized partial indicator in the i-th period;

$P_{0 i}$ - the value of the partial indicator selected for the formation of the vector-standard in the i-th period.

Note that the taxonomic distance of the partial indicators from the vector $\mathrm{P}$ is used as an indicator of their deviation, and, accordingly, the impact on the level of the integral indicator of reputation risk of the bank and involves the calculation of several auxiliary indicators:

avarage distance between observations: $\bar{C}_{0}=\frac{1}{m} \sum_{i=1}^{m} \mathrm{Coi}$,

standard deviation $(\mathrm{S} 0)$ :

$S_{0}=\sqrt{\frac{1}{m} \sum_{m}^{1}\left(C_{o i}-\bar{C}_{0}\right)^{2}}$,

Maximum deviation from the generated vector: $C_{0}=\bar{C}_{0}+2 S_{0}$

The final stage of the study is to determine the integral index of reputation risk by the formula: $I R R_{i}=C_{i 0} / C_{0}(7)$

The results of the above depicted calculations we propose to present in the table. A.2. The taxonomic index in general reflects the dynamics of changes in the values of the characteristics of the groups under study (indicators of stimulants and stimulants), and the interpretation of this instrument is as follows: it acquires high values at low rates of stimulants (high disinfectants) and vice versa.

A qualitative interpretation of the reputation risk level of PJSC CB "PrivatBank" was performed on the basis of the Schedule of Determination of the density of Chaddock. Accordingly, the value of the integral indicator of reputational risk can reach values in the range from 0 to 1 , while its approximation to the lower limit indicates an increase in the value of reputational capital.

Integrated Indicators of Reputation Risk (IRRi) with the use of taxonomic analysis tools resulted in integrated indicators, the dynamics of which are shown in Figure 2. In addition, it is proposed to map reputational risk indexes separately for each of the Indicator Integral Indicators (IRRi) groups.

After conducting all necessary calculations there is a clear tendency to increase the reputational risk of PJSC CB "PrivatBank", which is explained by the growth of the distance of the partial indicators from the vectorstandard. So, as of January 1, 2014, the coefficient of distance is - 0,91, then by the end of 2016 the value of the indicator stopped at the level of 3,97. In order to understand what indicators have had the greatest impact on the final indicator of the bank's reputation level in each period, it is necessary to consider deviations of the values of partial indicators from the vector of the standard (Table A.2). From the data it becomes clear that in 2016, in terms of financial ratios, the financial leverage ratio had the most negative effect, due to a rather sharp decrease in the Bank's equity, as well as the return on capital (decreased by almost 4 times compared with the previous period). 


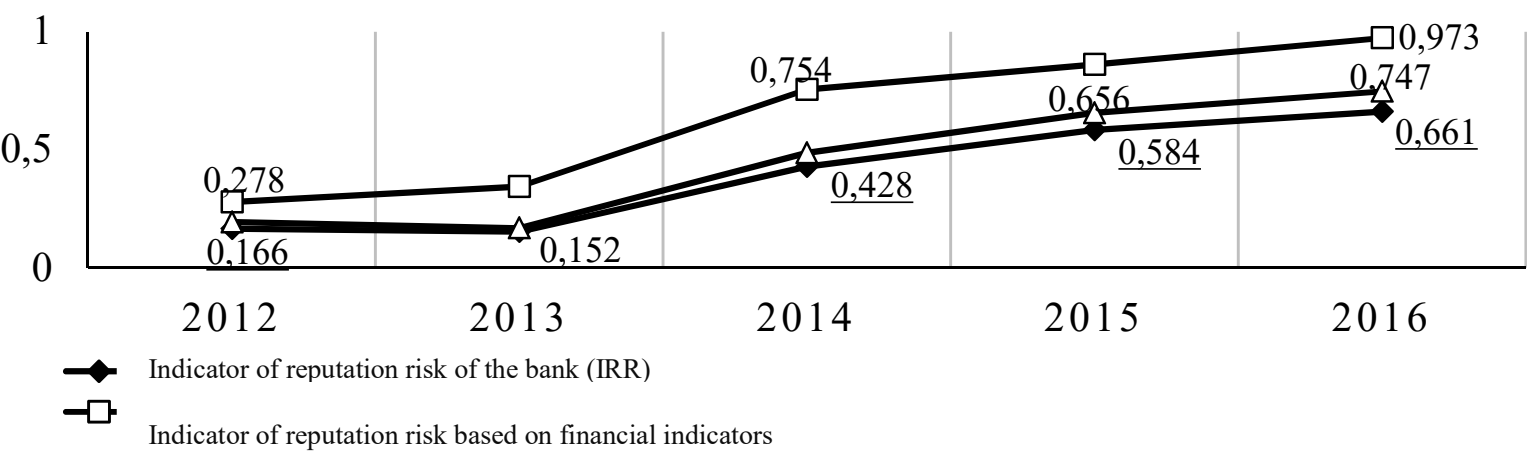

Figure 3. Dynamics of the integral indicator of reputational risk of PJSC CB "PrivatBank" as of 01.01.2013 - 01.01.2017.

In terms of the criteria for scoring the most significant is the reputation of owners, their connection with the political environment and the lobbying of their own interests at the expense of such links, as well as the criteria related to the transformation of other risks in the reputation (especially the issue of credit risk is of particular importance), inspections by the state regulatory bodies and the internal environment of the bank. From the point of view of 2014 and 2015, the situation in the criteria for ballrooming has not changed significantly, but it is worth noting the intensification in obtaining interbank loans. In other periods, the reputation risk of PJSC CB "PrivatBank" was at a low level. Providing some kind of projections for changes in the investigated risk in 2017-2018, its gradual decline is expected due to changes in the key indicators of the current valuation (owners, the political environment, risk transformation, capital, etc.), which, above all, will be due to the nationalization of the bank.

\section{Conclusion}

This work is a continuation of the study on the treatment of reputational risk, as well as the factors of influence on it, it should be noted that the main factor in the formation of a positive reputation of the bank is the whole complex of socio-political factors, with the emphasis on the level of customer confidence before bank, their readiness to cooperate and use of the offered services. The paper proposes an integral indicator of the bank's reputational risk level (IRRi), which combines the results of the analysis of financial indicators and the points of assessment, using taxonomic analysis tools. The qualitative interpretation of the results obtained is based on the scale of the definition of Chaddock's interrelations. After conducting all necessary calculations a clear tendency to increase reputation risk of PJSC CB "PrivatBank" is determined, which is explained by the growth of the distance of the partial indicators from the vector-standard. In 2016, in terms of financial ratios, the financial leverage ratio had the most negative impact on the value of the integral indicator, due to the rather sharp decrease of the Bank's equity capital, as well as the return on capital (decreased by almost 4 times compared with the previous period). In terms of benchmarking criteria, the reputation of the owners is the most significant, their connection to the political environment and the lobbying of their own interests at the expense of such links, as well as the criteria related to the transformation of other risks into the reputation (especially the issue of credit risk is of particular importance), inspections from the state regulatory bodies and the bank's internal environment. From the point of view of 2014 and 2015, the situation in the criteria for ballrooming has not changed significantly, but it is worth noting the intensification in obtaining interbank loans. In other periods, the reputation risk of PJSC CB "PrivatBank" was at a low level. Providing some kind of projections for changes in the investigated risk in 2017-2018, its gradual decline is expected due to changes in the key indicators of the current valuation (owners, the political environment, risk transformation, capital, etc.), which, above all, will be due to the nationalization of the bank.

\section{References}

1. Needed, A Holistic Approach to Reputation Risk Management in Banks. Infosys Finacle Thought Paper. Retrieved from: www.infosys.com/finacle.

2. Connie M. Friesen Defining and Managing Reputation Risk. IIB Risk Management-Compliance Seminar Managing Reputation Risk in an Internet World. Retrieved from: http://www.iib.org/news/370608/-RiskManagement-Compliance-Seminar-Speaker-Presentations.htm.

3. Metodychni rekomendatsii shchodo orhanizatsii ta funktsionuvannia system ryzyk-menedzhmentu v bankakh Ukrainy. Skhvaleni postanovoiu Pravlinnia Natsionalnoho banku Ukrainy vid 02.08.2004 № 361. [Methodical recommendations on the organization and functioning of risk management systems in banks of Ukraine. Approved 
by the Resolution of the Board of the National Bank of Ukraine dated 02.08.2004 № 361]. Retrieved from: http://zakon4.rada.gov.ua/laws/show/v0361500-04.

4. Federalna rezervna systema SShA: ofitsiina veb-storinka. [US Federal Reserve: official web page]. Retrieved from: www.federalreserve.gov

5.Bank Anhlii: ofitsiina veb-storinka. [Bank of England: official web page]. Retrieved from: http://www.bankofengland.co.uk/.

6. Bundesbank : ofitsiinyi veb-portal. [Bundesbank: official web-portal]. Retrieved from: htps:www. bundesbank.de.

7. Basel II. International Convergence of Capital Measurement and Capital Standards A Revised Framework. Basel. November, 2005. URL: http://www.bis.org/publ/bcbs128.htm.

8. Gary van Vuuren Dodd-Frank and risk-taking: reputation impact in banks. Retrieved from: https://businessperspectives.org/banks-and-bank-systems/dodd-frank-and-risk-taking-reputation-impact-in-banks.

9. Giorgino M. An integrated framework for reputational risk assessment: modelling reputational risk as an indirect effect. Retrieved from: https://www.politesi.polimi.it/107897/3/2015_04_Professione.pdf.

10. Kolesnik Ya. V. (2016). Statystychni pidkhody do otsiniuvannia dilovoi reputatsii bankivskykh ustanov. Statystyka Ukrainy. [Statistical approaches to the assessment of business reputation of banking institutions. Statistics of Ukraine]. № 4. C. 27-32.

11. Jackson K. T. (2009). Building Reputational Capital: Strategies for Integrity and Fair Play that Improve the Bottom Line, Oxford University Press, 240 p.

12. Reputation Risk Explosion: Weaponization of Social Media, False News and Outsized Expectations Causing Increased Damage to Corporate Reputations. Retrieved from: http://www.steelcityre. com/ content/ 2016/ ReputationRisk-December-2016.pdf.

13. Sturm P. (2013). Operational and Reputational Risk in the European Banking Industry: The Market Reaction to Operational Risk Events. Journal of Economic Behavior \& Organization, 85, 133-147.

14. Wyman O. Reputation risk on the rise. Retrieved from: http://www.oliverwyman.com/ content/ publications/2016/Wyman-Reputation-Risk-On-The-Rise.pdf.

15. Natsionalne reitynhove ahentstvo Riuryk : ofitsiina veb-storinka. [National rating agency Rurik: official web page]. Retrieved from: http://rurik.com.ua/.

16. Natsionalnyi bank Ukrainy: ofitsiina veb-storinka. [National Bank of Ukraine: official web-site]. Retrieved from: https://www.bank.gov.ua.

17. Reitynh zhyttiezdatnosti ukrainskykh bankiv. (2016). [Rating of viability of Ukrainian banks]. Retrieved from: http://forbes.net.ua/ua/magazine/forbes/140988786424377-rejting-zhittezdatnosti-ukrayinskih-bankiv-2016.

18. Somyk A. V. Dovira do bankiv v Ukraini. [Somik A. V. Trust in banks in Ukraine]. Retrieved from: https://www.bank.gov.ua/doccatalog/document?id=70688.

19. Amerykanskyi instytut suspilnoi dumky «Instytut Hellapa» Ukraini : ofitsiina veb-storinka. [American Institute of Public Opinion "Gallup Institute" Ukraine: official web page]. Retrieved from: http://www.gallup.com/home.aspx.

20. PAT KB «PryvatBank»: ofitsiina veb-storinka. [PJSC KB «PrivatBank»: the official web-page]. Retrieved from: https://privatbank.ua/.

21. Buriak A. V., Rymar A.O. (2017). Reputatsiini ryzyky bankivskoho sektoru: instytutsiini proiavy suspilnoi doviry do finansovoho sektoru krainy. Ekonomika. Finansy. [Buryak AV, Rimar A.O. Reputational risks of the banking sector: institutional manifestations of public confidence in the financial sector of the country. Economy. Finances], 12(3), 10-14.

\section{Appendix A}

Table A.1. Standardized system of partial indicators of reputation risk of PJSC CB "PrivatBank" as of 01.01.2013 - 01.01.2017.

\begin{tabular}{|l|l|l|l|l|l|l|l|}
\hline Indicator & 2012 & 2013 & 2014 & 2015 & 2016 & Stimulator & Dehumidifier \\
\hline$K_{2}$ & 0.78 & 0.97 & 0.77 & 0.76 & 1.72 & \\
\hline$K_{3}$ & 1.08 & 1.00 & 0.89 & 1.05 & 0.98 & & \\
\hline$K_{4}$ & 1.06 & 0.91 & 1.14 & 0.83 & 1.06 & & \\
\hline$K_{7}$ & 1.52 & 1.34 & 1.47 & 0.53 & 0.14 & & \\
\hline$K_{14}$ & 0.80 & 0.51 & 1.39 & 1.27 & 1.03 & & \\
\hline$K_{16}$ & 1.16 & 1.18 & 0.98 & 0.79 & 0.88 & & \\
\hline$I_{1}$ & 0.33 & 0.33 & 1.00 & 1.67 & 1.67 & & \\
\hline$I_{2}$ & 1.00 & 1.00 & 1.00 & 1.00 & 1.00 & & \\
\hline$I_{3}$ & 1.00 & 1.00 & 1.00 & 1.00 & 1.00 & & \\
\hline
\end{tabular}


Table A.1. (cont.). Standardized system of partial indicators of reputation risk of PJSC CB "PrivatBank" as of 01.01.2013 - 01.01.2017.

\begin{tabular}{|l|l|l|l|l|l|l|l|}
\hline$I_{4}$ & 0.29 & 0.29 & 1.47 & 1.47 & 1.47 & & \\
\hline$I_{5}$ & 1.00 & 1.00 & 1.00 & 1.00 & 1.00 & & \\
\hline$I_{6}$ & 0.45 & 0.45 & 1.36 & 1.36 & 1.36 & & \\
\hline$I_{7}$ & 0.71 & 0.71 & 1.19 & 1.19 & 1.19 & & \\
\hline$O_{1}$ & 0.45 & 0.45 & 1.36 & 1.36 & 1.36 & & \\
\hline$O_{2}$ & 1.19 & 0.24 & 1.19 & 1.19 & 1.19 & & \\
\hline$O_{3}$ & 1.00 & 1.00 & 1.00 & 1.00 & 1.00 & & \\
\hline$O_{4}$ & 1.00 & 1.00 & 1.00 & 1.00 & 1.00 & & \\
\hline$O_{5}$ & 0.29 & 0.88 & 0.88 & 1.47 & 1.47 & & \\
\hline$O_{6}$ & 0.29 & 0.88 & 0.88 & 1.47 & 1.47 & & \\
\hline$B_{1}$ & 0.71 & 0.71 & 0.71 & 0.71 & 2.14 & & \\
\hline$B_{2}$ & 0.33 & 0.33 & 1.00 & 1.67 & 1.67 & & \\
\hline
\end{tabular}

Table A.2. Dynamics of auxiliary settlements for finding the integral indicator of reputation risk of PJSC CB "PrivatBank" as of 01.01.2013 - 01.01.2017.

\begin{tabular}{|c|c|c|c|c|c|}
\hline \multirow{2}{*}{ Indicator } & 2012 & 2013 & 2014 & 2015 & 2016 \\
\hline & $\left(\mathrm{P}_{\mathrm{ij}}-\mathrm{P}_{0 \mathrm{i}}\right)^{2}$ & $\left(\mathrm{P}_{\mathrm{ij}}-\mathrm{P}_{0 \mathrm{i}}\right)^{2}$ & $\left(P_{i j}-P_{0 i}\right)^{2}$ & $\left(\mathrm{P}_{\mathrm{ij}}-\mathrm{P}_{0 \mathrm{i}}\right)^{2}$ & $\left(P_{i j}-P_{0 i}\right)^{2}$ \\
\hline$K_{2}$ & 0.000 & 0.000 & 0.000 & 0.05 & 0.921 \\
\hline$K_{3}$ & 0.000 & 0.001 & 0.035 & 0.01 & 0.010 \\
\hline$K_{4}$ & 0.006 & 0.092 & 0.000 & 0.05 & 0.006 \\
\hline$K_{7}$ & 0.000 & 0.976 & 0.002 & 0.03 & 1.913 \\
\hline$K_{14}$ & 0.082 & 0.579 & 0.763 & 0.00 & 0.269 \\
\hline$K_{16}$ & 0.000 & 0.154 & 0.043 & 0.00 & 0.090 \\
\hline$I_{1}$ & 0.000 & 1.778 & 0.444 & 0.00 & 1.778 \\
\hline$I_{2}$ & 0.000 & 0.000 & 0.000 & 0.00 & 0.000 \\
\hline$I_{3}$ & 0.000 & 0.000 & 0.000 & 0.00 & 0.000 \\
\hline$I_{4}$ & 0.000 & 1.384 & 1.384 & 0.00 & 1.384 \\
\hline$I_{5}$ & 0.000 & 0.000 & 0.000 & 0.00 & 0.000 \\
\hline$I_{6}$ & 0.000 & 0.826 & 0.826 & 0.00 & 0.826 \\
\hline$I_{7}$ & 0.000 & 0.227 & 0.227 & 0.00 & 0.227 \\
\hline$O_{1}$ & 0.000 & 0.826 & 0.826 & 0.00 & 0.826 \\
\hline $\mathrm{O}_{2}$ & 0.907 & 0.907 & 0.907 & 0.00 & 0.907 \\
\hline $\mathrm{O}_{3}$ & 0.000 & 0.000 & 0.000 & 0.00 & 0.000 \\
\hline $\mathrm{O}_{4}$ & 0.000 & 0.000 & 0.000 & 0.00 & 0.000 \\
\hline$O_{5}$ & 0.000 & 1.384 & 0.346 & 0.35 & 1.384 \\
\hline$O_{6}$ & 0.000 & 1.384 & 0.346 & 0.35 & 1.384 \\
\hline$B_{I}$ & 0.000 & 0.000 & 0.000 & 0.00 & 2.041 \\
\hline$B_{2}$ & 0.000 & 1.778 & 0.444 & 0.00 & 1.778 \\
\hline$C_{0 i}$ & 1.00 & 0.91 & 2.57 & 3.51 & 3.97 \\
\hline $\bar{C}_{0}$ & & & 2.39 & & \\
\hline$C_{0}$ & & & 6.01 & & \\
\hline$S_{0}$ & & & 1.26 & & \\
\hline IRR & 0.166 & 0.152 & 0.428 & 0.584 & 0.661 \\
\hline
\end{tabular}

Table A.3. Dynamics of deviations of partial indicators for assessing the level of reputation risk of the bank from the vector-standard as of 01.01.2013 - 01.01.2017.

\begin{tabular}{|l|c|c|c|c|c|}
\hline Indicator & 2012 & 2013 & 2014 & 2015 & 2016 \\
\hline$K_{2}$ & 0.02 & 0.21 & 0.01 & 0.00 & 0.96 \\
\hline$K_{3}$ & 0.00 & 0.08 & 0.19 & 0.03 & 0.10 \\
\hline$K_{4}$ & 0.08 & 0.23 & 0.00 & 0.30 & 0.08 \\
\hline$K_{7}$ & 0.00 & 0.18 & 0.05 & 0.99 & 1.38 \\
\hline$K_{I 4}$ & 0.29 & 0.00 & 0.87 & 0.76 & 0.52 \\
\hline
\end{tabular}


Table A.3. Dynamics of deviations of partial indicators for assessing the level of reputation risk of the bank from the vector-standard as of 01.01.2013 - 01.01.2017.

\begin{tabular}{|l|l|l|l|l|l|}
\hline$K_{16}$ & 0.02 & 0.00 & 0.21 & 0.39 \\
\hline$I_{1}$ & 0.00 & 0.00 & 0.67 & 1.33 \\
\hline$I_{4}$ & 0.00 & 0.00 & 1.18 & 1.33 \\
\hline$I_{6}$ & 0.00 & 0.00 & 0.91 & 0.18 \\
\hline$I_{7}$ & 0.00 & 0.00 & 0.48 & 0.91 \\
\hline$O_{1}$ & 0.00 & 0.00 & 0.95 & 0.48 & 0.95 \\
\hline$O_{2}$ & 0.95 & 0.59 & 0.59 & 0.91 \\
\hline$O_{5}$ & 0.00 & 0.59 & 0.59 & 1.18 \\
\hline$O_{6}$ & 0.00 & 0.00 & 0.00 & 1.18 \\
\hline$B_{1}$ & 0.00 & 0.00 & 0.67 & 1.18 \\
\hline$B_{2}$ & 0.00 & \multicolumn{2}{|c|}{0.00} \\
\hline
\end{tabular}

\section{Appendix B}

Table B.1. Criteria for the ballroom evaluation of the image component of reputation risk of PJSC CB "PrivatBank"

\begin{tabular}{|c|c|c|c|}
\hline Criterion & Value & Evaluation options & M \\
\hline 1 & 2 & 3 & 4 \\
\hline \multirow{3}{*}{$\begin{array}{l}\text { Reputation of founders } \\
\text { and major } \\
\text { shareholders (I1) }\end{array}$} & \multirow[t]{3}{*}{$\begin{array}{l}\text { Displays the opinion of the main counteragents } \\
\text { of the bank concerning its founders }\end{array}$} & The founders' reputation is close to impeccable & 1 \\
\hline & & $\begin{array}{l}\text { The founders of the bank can be defined as reliable business } \\
\text { partners }\end{array}$ & 3 \\
\hline & & $\begin{array}{l}\text { Founders are considered to be unreliable, dishonest business } \\
\text { partners }\end{array}$ & 5 \\
\hline \multirow[t]{3}{*}{$\begin{array}{l}\text { Bank's social and } \\
\text { business activity }\left(I_{2}\right)\end{array}$} & \multirow[t]{3}{*}{$\begin{array}{l}\text { Characterizes the level of participation of the } \\
\text { bank in the socio-economic life of the region }\end{array}$} & $\begin{array}{l}\text { The Bank is an active participant of various kinds of social } \\
\text { programs and events, charitable projects, etc. }\end{array}$ & 1 \\
\hline & & The Bank participates in such events on an irregular basis & 3 \\
\hline & & The Bank does not participate in such events & 5 \\
\hline \multirow{3}{*}{$\begin{array}{l}\text { Perception of the } \\
\text { market of banking } \\
\text { products offered by } \\
\text { the bank }\left(I_{3}\right)\end{array}$} & \multirow[t]{3}{*}{$\begin{array}{l}\text { Characterizes the success of the Bank's } \\
\text { introduction of new services and products, } \\
\text { entering new segments of the market }\end{array}$} & $\begin{array}{l}\text { Customers prefer most of the bank's services compared to } \\
\text { competitors, the experience of negative product introduction is } \\
\text { minimal. }\end{array}$ & 1 \\
\hline & & $\begin{array}{l}\text { Bank services are well received by the market, cases of negative } \\
\text { launch of products are isolated }\end{array}$ & 3 \\
\hline & & $\begin{array}{l}\text { In most cases, the customer prefers the services of competitors, } \\
\text { the share of unsuccessful projects is increasing }\end{array}$ & 5 \\
\hline \multirow{3}{*}{$\begin{array}{l}\text { Liaison of the } \\
\text { shareholders with the } \\
\text { political environment, } \\
\text { lobbying the interests } \\
\text { of the bank on the basis } \\
\text { of political ties }\left(I_{4}\right)\end{array}$} & \multirow{3}{*}{$\begin{array}{l}\text { Characterizes the ownership of shareholders to } \\
\text { the political life of the region and the country, } \\
\text { the possibility of obtaining additional benefits at } \\
\text { the expense of power relations }\end{array}$} & $\begin{array}{l}\text { The main shareholders are in no way connected with the political } \\
\text { environment }\end{array}$ & 1 \\
\hline & & $\begin{array}{l}\text { The owners of the bank have connections with the political life of } \\
\text { the region, but this is not connected with the bank's activities. }\end{array}$ & 3 \\
\hline & & $\begin{array}{l}\text { There are cases of disclosure of the relations of shareholders with } \\
\text { political forces, as well as the obtaining of competitive advantages } \\
\text { on their basis. }\end{array}$ & 5 \\
\hline \multirow[t]{3}{*}{$\begin{array}{l}\text { Level of } \quad \text { Bank } \\
\text { Disclosure }\left(I_{5}\right)\end{array}$} & \multirow[t]{3}{*}{$\begin{array}{l}\text { Characterizes transparency indicators of the } \\
\text { bank's activities }\end{array}$} & $\begin{array}{l}\text { The Bank discloses relevant and maximally complete information } \\
\text { about its activities }\end{array}$ & 1 \\
\hline & & The bank discloses information, but only in some aspects & 3 \\
\hline & & $\begin{array}{l}\text { The Bank does not take measures to improve the transparency of } \\
\text { activities, only in terms of mandatory aspects. }\end{array}$ & 5 \\
\hline \multirow{2}{*}{$\begin{array}{l}\text { Ineffective } \\
\text { counteraction to the } \\
\text { legalization of } \\
\text { proceeds from crime, } \\
\text { as well as other } \\
\text { unlawful activities }\left(I_{6}\right)\end{array}$} & \multirow{2}{*}{$\begin{array}{l}\text { Characterizes the presence or absence of data on } \\
\text { the contact of the owners or employees of the } \\
\text { bank with illegal organizations and operations }\end{array}$} & $\begin{array}{l}\text { Cases of accusations of owners and employees in participation in } \\
\text { illegal activity are absent. }\end{array}$ & 1 \\
\hline & & Situations of this type are present in the activities of the bank & 5 \\
\hline \multirow[t]{3}{*}{$\begin{array}{l}\text { Impairment of image at } \\
\text { the state level }\left(I_{7}\right)\end{array}$} & \multirow{3}{*}{$\begin{array}{l}\text { Displays the mood of the population in the } \\
\text { confidence in the banking system in general, } \\
\text { which is formed under the influence of socio- } \\
\text { political and economic situation in the state. }\end{array}$} & $\begin{array}{l}\text { Trust in the banking system is characterized by a rather high level, } \\
\text { the volume of funds outside banks is gradually decreasing }\end{array}$ & 1 \\
\hline & & $\begin{array}{l}\text { Trust in banking institutions is changing in dynamics, there is } \\
\text { experience of previous crisis periods }\end{array}$ & 3 \\
\hline & & $\begin{array}{l}\text { The society is dominated by panic and sharply negative attitudes } \\
\text { towards banks }\end{array}$ & 5 \\
\hline
\end{tabular}


Table B.2 Criteria for rating the organizational and functional component of reputation risk of PJSC CB "PrivatBank"

\begin{tabular}{|c|c|c|c|}
\hline Criterion & Value & Evaluation options & \\
\hline 1 & 2 & 3 & 4 \\
\hline \multirow[t]{3}{*}{$\begin{array}{l}\text { Quality of customer } \\
\text { service, cases of negative } \\
\text { appeals and complaints } \\
\left(O_{I}\right)\end{array}$} & \multirow{3}{*}{$\begin{array}{l}\text { Characterizes the quality of bank customer } \\
\text { service, the number of complaints received, } \\
\text { the response time to negative reviews, and the } \\
\text { availability of separate quality management } \\
\text { services and dealing with dissatisfied } \\
\text { customers. }\end{array}$} & $\begin{array}{l}\text { Quality of service is considered to be one of the best in the market, } \\
\text { the bank quickly responds to negative feedback received, there is } \\
\text { a separate service to work with the client base. }\end{array}$ & 1 \\
\hline & & $\begin{array}{l}\text { The Bank has a small negative dynamics of closing deposits, the } \\
\text { number of complaints is medium-static, the bank sometimes lags } \\
\text { in response to received negative hits. }\end{array}$ & 3 \\
\hline & & $\begin{array}{l}\text { Public service is absent, monitoring and processing of feedback } \\
\text { are not carried out, the impact of complaints and feedback on the } \\
\text { formation of negative reputation is significant. }\end{array}$ & 5 \\
\hline \multirow{2}{*}{$\begin{array}{l}\text { Litigation relating to the } \\
\text { Bank's activities }\left(O_{2}\right)\end{array}$} & \multirow{2}{*}{$\begin{array}{l}\text { Displays the presence or absence of opening } \\
\text { of court proceedings related to the activities } \\
\text { of the bank }\end{array}$} & Proceedings were not conducted & 1 \\
\hline & & Litigation took place during the period. & \\
\hline \multirow[t]{3}{*}{$\begin{array}{l}\text { Monitoring of bank } \\
\text { messages in mass media } \\
\left(O_{3}\right)\end{array}$} & \multirow{3}{*}{$\begin{array}{l}\text { Characterizes a strategy for working with } \\
\text { information on the bank in the press and other } \\
\text { media sources, responding to received } \\
\text { messages }\end{array}$} & $\begin{array}{l}\text { The Bank regularly monitors media reports, takes all necessary } \\
\text { steps to create or restore a positive reputation that may change } \\
\text { under their influence. }\end{array}$ & 1 \\
\hline & & $\begin{array}{l}\text { The monitoring of media information is not of a regular nature, } \\
\text { but only in the case of high scandals and shocks }\end{array}$ & 3 \\
\hline & & & 5 \\
\hline $\begin{array}{l}\text { The level of popularity of } \\
\text { its own payment system } \\
\left(\mathrm{O}_{4}\right)\end{array}$ & $\begin{array}{l}\text { Displays the connection between the concepts } \\
\text { of "quantity-riskiness". The greater the } \\
\text { number of payments and operations, the } \\
\text { greater the likelihood of a threat. }\end{array}$ & $\begin{array}{l}\text { The payment system is widespread, is one of the most popular } \\
\text { with customers. }\end{array}$ & 5 \\
\hline \multirow{3}{*}{$\begin{array}{l}\text { The level of popularity of } \\
\text { its own payment system } \\
\left(O_{4}\right) \\
\text { Related to transformation } \\
\text { of other risks (credit) } \\
\left(O_{5}\right)\end{array}$} & \multirow{3}{*}{$\begin{array}{l}\text { Displays the connection between the concepts } \\
\text { of "quantity-riskiness". The greater the } \\
\text { number of payments and operations, the } \\
\text { greater the likelihood of a threat. } \\
\text { Characterizes the transformational processes } \\
\text { of credit risk in reputational }\end{array}$} & $\begin{array}{l}\text { The payment system is not very popular among others on the } \\
\text { market }\end{array}$ & 3 \\
\hline & & Your own payment system has been widespread or absent & 1 \\
\hline & & $\begin{array}{l}\text { Stable indicators of the ratio of loans issued to related parties of } \\
\text { the bank, reducing the amount of overdue debt and improving the } \\
\text { quality of the loan portfolio }\end{array}$ & 1 \\
\hline \multirow{3}{*}{$\begin{array}{l}\text { Related to transformation } \\
\text { of other risks (credit) } \\
\left(O_{5}\right) \\
\text { Results of bank } \\
\text { inspections by state } \\
\text { regulation bodies }\left(O_{6}\right)\end{array}$} & \multirow{3}{*}{$\begin{array}{l}\text { Characterizes the transformational processes } \\
\text { of credit risk in reputational } \\
\text { Displays the results of bank inspections by the } \\
\text { National Bank of Ukraine, as well as other } \\
\text { state regulation bodies }\end{array}$} & $\begin{array}{l}\text { The insignificant increase in lending related to the bank, the } \\
\text { gradual build-up of overdue debts and a decrease in the quality of } \\
\text { the loan portfolio }\end{array}$ & 3 \\
\hline & & $\begin{array}{l}\text { Large volumes of lending to related parties, rapid increase in } \\
\text { overdue debts (over } 50 \% \text { ) and quality of loan portfolio }\end{array}$ & 5 \\
\hline & & $\begin{array}{l}\text { The result of the inspections is positive, or the absence of the } \\
\text { circumstances envisaging their conduct }\end{array}$ & 1 \\
\hline \multirow{2}{*}{$\begin{array}{l}\text { Results of bank } \\
\text { inspections by state } \\
\text { regulation bodies }\left(O_{6}\right)\end{array}$} & \multirow{2}{*}{$\begin{array}{l}\text { Displays the results of bank inspections by the } \\
\text { National Bank of Ukraine, as well as other } \\
\text { state regulation bodies }\end{array}$} & $\begin{array}{l}\text { The bank had drawbacks and comments, but they are not material } \\
\text { and can be eliminated without additional sanctions. }\end{array}$ & 3 \\
\hline & & $\begin{array}{l}\text { The results of inspections are mostly negative, with possible } \\
\text { catastrophic consequences. }\end{array}$ & 5 \\
\hline
\end{tabular}

Table B.3. Criteria for balancing the internal environment of PJSC CB "PrivatBank" as a component of reputational risk

\begin{tabular}{|c|c|c|c|}
\hline Criterion & Value & Evaluation options & \\
\hline 1 & 2 & 3 & 4 \\
\hline \multirow[t]{3}{*}{$\begin{array}{l}\text { Processes of internal corporate } \\
\text { communications }\left(B_{l}\right)\end{array}$} & \multirow{3}{*}{$\begin{array}{l}\text { Characterizes fixed acts of unethical } \\
\text { behavior of employees; low level of } \\
\text { perception of the bank by employees } \\
\text { (satisfaction and loyalty), problems of } \\
\text { internal corporate culture. }\end{array}$} & $\begin{array}{l}\text { The employee's behavior is fully in line with ethical standards, } \\
\text { satisfaction with the working conditions and loyalty to the bank are } \\
\text { at the highest level. }\end{array}$ & 1 \\
\hline & & $\begin{array}{l}\text { The facts of unethical behavior of workers, satisfaction with } \\
\text { working conditions and loyalty are fixed. }\end{array}$ & 3 \\
\hline & & $\begin{array}{l}\text { A large number of internal conflicts have been recorded, most of } \\
\text { the employees are dissatisfied with the existing working } \\
\text { conditions, there is no loyalty to the bank. }\end{array}$ & 5 \\
\hline \multirow{3}{*}{$\begin{array}{l}\text { Adequacy of the existing system } \\
\text { of internal control and audit }\left(B_{2}\right)\end{array}$} & \multirow{3}{*}{$\begin{array}{l}\text { Characterizes the effectiveness of internal } \\
\text { control systems, their independence in } \\
\text { decision making and risk reduction }\end{array}$} & The system is fully adequate and independent. & 1 \\
\hline & & The system is generally adequate & 3 \\
\hline & & $\begin{array}{l}\text { The work of the service does not contribute to reducing the level of } \\
\text { bank risks }\end{array}$ & 5 \\
\hline
\end{tabular}

